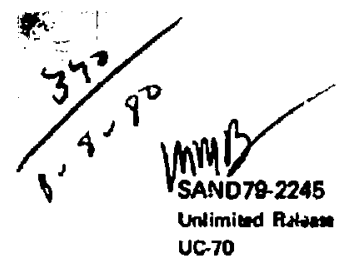

\title{
Di. 1622
}

\section{The Strategy for Assessing the Technical, Environmental, and Engineering Feasibility of Subseabed Disposal}

D. Richard Andarson, D. Glenn Boyer, David Deses, Henry Herrman, John Kelly, Deniel M. Talbert 
SAND79-2245

Distribueins

Inlimited Release

Cacesury itio

Printed July 1980

THF STRAHLCY FUS ISSESSINC THE TECHNICAL, ENVIRONYFNTAL, AND ENC LAEERINC; YEASIBILITY OF SUBSEABEN TISPOSAL

3. Ri:hard Anderson and Daniel $M$. Talbert Siabed Programs Division 4536 Sandia National Labnratories

Albuguerque, NM 871 R5

David Resse

Progran for beicnte and interrational Affats: Harvard l'nivereits, Cambridge, SA $0 \geq 138$

i. Gent bover

Iffite of haste isclarion. DOE'ONhe:

kyshineton, DC 20545

Henry Herrmann

John kelly

Complex Systems Researih

l'niversity of New Hampshira

nurham, NH 038?4

\begin{abstract}

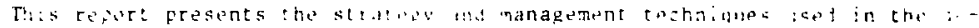

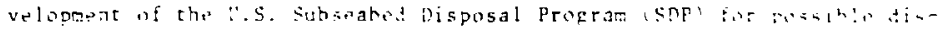

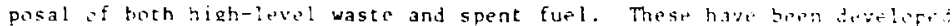

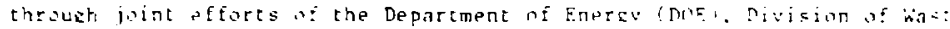
Isslation, the Sandia Tiechnical Proeram Manaqer, tho Irchnital Prokam

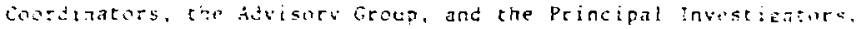

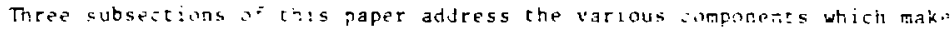

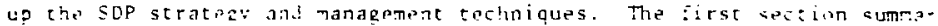
rizes the l'.s. DC: tizh-level waste and spent-fue! disposa program and the pusition that the sup retup:es withis that provran. The second section. the subseabed program Plan, addresses the tecrisial and adninis-

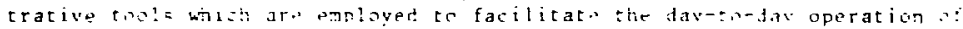
the sop. The chizd stitlon addesses the current sturies and future plans

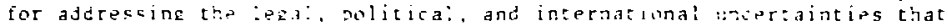
nust be rasived before the SDP rejches the final inainesting ptases.
\end{abstract}

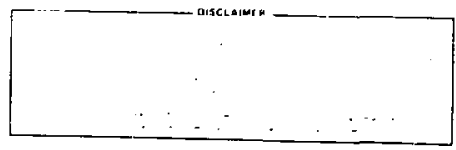




\section{CONTENTS}

\section{Page}

Introduction

Nuclear Waste Management Strategy

Subseabed Program Plan: Strategy and Management Methods

Subseabed Strategy and Management Methods

Management Methods

References

\section{ILLUSTRATIONS}

\section{Figure}

1 NwTS Program Management Chatt

2 Programmatic Activicy Chart 
THE STRATEGY FOR ASSESSING THE TECHNICAL, ENYIRONMENTAL, AND ENGINEERING FEASIBILITY OF SUBSEABED DISPOSAL

\author{
Int roduction
}

The assessmenc $n$ ? geologic disposal of radioactive waste benuth the seabed is part of the Department of Energy (DOF) National waste Termina: Storage (NhTS) Program. The overall goal of the NuTS Program is te identify and develop technolosies that will provide a high degree of acsuran:o that existing and fucure radioactive wastes can be isolated from the binsphere in a safe, environmentally acceptable manner and to proy ido nu:essary facilities to achieve this isolition.

The majur thrust of the DOE whtS Program is towiat the ianlat isn a: waste in stable geologic formations within the contigunus l'nited statre. at deptis reachable by corventional mining methods. The geologia: tar mations of primary interest are rock salt, basalt, granite, shali, ח volcanic cufis. A prime alternative is subseabed formations, A sistmat ic assessment af subseabed formations has identifind vist arras of tarr ocean sediments which are considered to be some ns the more stah:.. formations on the earth.

The Subseabed Disposal Program is investigating the feasintili: o: disposal within these sediments. The near-certr objectives are to 111 assec the technical feasibility of the cancept of anginered amolacmomt or dppropitately solidified and packaged high-level wastes within :h.. table deep sea sediments and (2) develop and maintain the capabilitv to rvaluate and cooperate with other nations ocean disposal programs. 
In thi late 1950s, waste management strategies turnes from short-tem alut ivis to an increasing emphasis on the development of wasto disposal

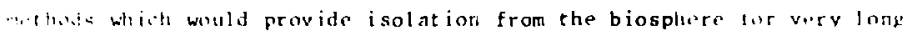

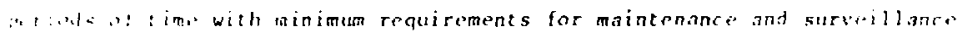
1. ...... A th. same $1: m$, , sommersialization of nuclpar technolorv brean

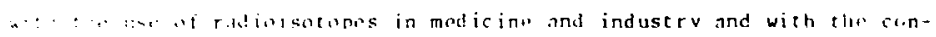

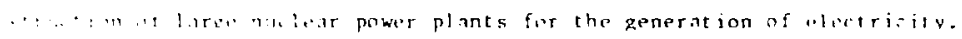

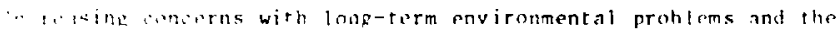

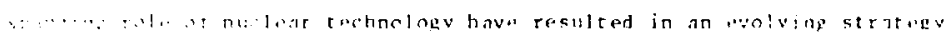

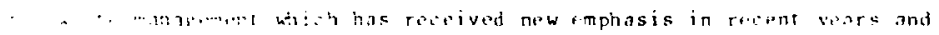

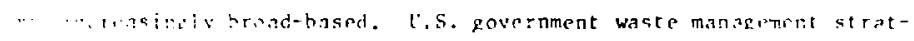

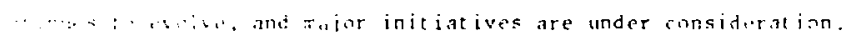

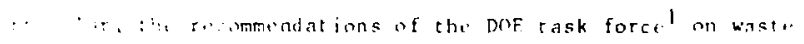

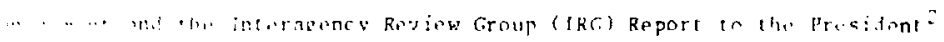
. r basti manarement contain spe, if is recommendations which ar. $\therefore \quad \therefore$ as basis tor Hir current programs.

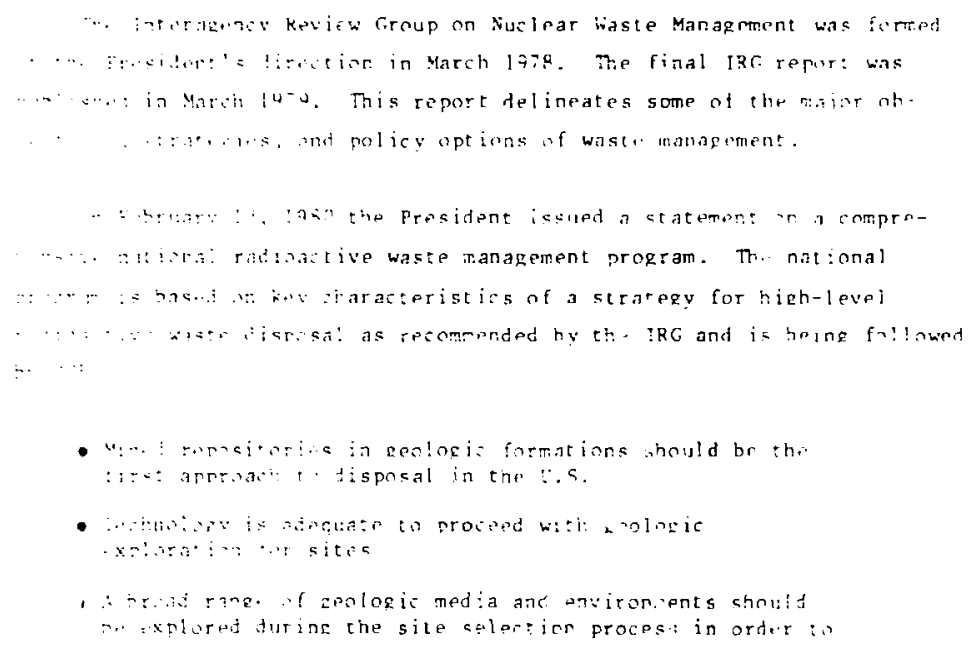


have available several sites which are geographically distributed

- Deep ocean sediments should be pualuated as potential alternatives

- Technical conservatism should be used for the repository

- A systems appruach should be used to select the geologit invironment, repository site, and wasteiparkage fom

- Proeram flexibility and timing should consider the important role played by away-from-reactor storage of sornt fuel

The DOE cannot unilaterally decide on and implement a long-tprm wasto disposal program. The Energy Reorganization Act of 1974 rpquires that facilities for the long-term storage of high-level waste be licensut hy the Nuclear Regulatory Commission. The Nat innal Environmental Policr Aat of 1909 requires. 't appropriate Environmental Impact Statements bo prespared as part of the decision-making process by the public state, spirial interest eroups, and Federal agencies.

A Aratt Generic Enviromental Impact Statement (GEIS) on the manacement of comercially generated radioactive wasce was issued ia dipri: 14-9. A series of public hearings airing this document was held in $19^{-4}$. comments trum these public hearings and other writcen coments are rutrently being considered, and a final GElS is being prepared, The (a)! focuses on hizh-level wastes in the form of either discarded speitt-turl elements or canisters of waste from the repracessine of such elements. Nini alternative concopts for disposal of long-lived radicactive whise הT. atdressed:

- Ceologie disposal usine conventional mining techniques

- Very reep hole disposal

- Rock Mtlting

- Isiand disposal

- ubseabed disposal

- In-shaft disposal 
- Reverse well disposal

- Treatment by transmutation

- Disposal in space

These concepts constitute a comptehersive set of waste management trinologies. It is presently thought that afditional disposal modes that could be identified as potential alternatives would merely be variations If one or more of these concepis. As part of the repository selection procuss, site-specific Environmental Impact Statements will be prepared.

Th: National Waste Terminal Storage (NWTS) Program encompasses tre work hruakdown structures and strategies to investigate and develop the colinolopios for selection, design, constriction, and operation of Federal roposiznesis. The NWTS program is comprised of four subprograms, each investignt ing isolation systems centered on different host media and specitic related tochnologies:

1. The of fice of Nuclear waste Isolation (ONWI) Program thus far has concentrated on systems associated with iock salt formations with some work on granite and shale. The investigation into other hard rock Enrations is being expancied.

2. The Basalt Waste Isolation Program (BWIP) is investigating the basalt formations found within the DOE Hanford Reservation.

- Thr Nevada Nuclear Waste Storage Investigation Program is investigating potential systens involving primarily aranitf. shale, and tuffs at the DOF Nevada Test Sice. I $\mathrm{L}$ is currently focusing on volcanir tuffs.

$\rightarrow$ M. Subspabed Disposal Prngram is investigating thr A, De?:in: Clay sediments.

The primary gaai of the composite NwTS program is to ident ify specific candidatt Incations ther might qualifs as repository sites. The acceptance of these sites and associated systems will be gaged through comparison with criteria, guidelines, and regulations currentiv bring formulated by the i.S. Nuclnar Regulatory Commission (NRC) and the b.S. Environtental Protecion Agency. In the case of subseabej disposal, 
criteria, guidelines, and regulations of appropriate international regulatory bodies ane internatinnal treaties wij also have to he considered. In the meantime, DOE is developing its own criteria to provide dirertion for the MTS program efforts by establising ganaral performance criteria for the waste isolation sysem and general functional criteria" for the site, repository, and waste package components of the systom. "u." realtionship among the NWTS Progran participants is shown in Figure!.

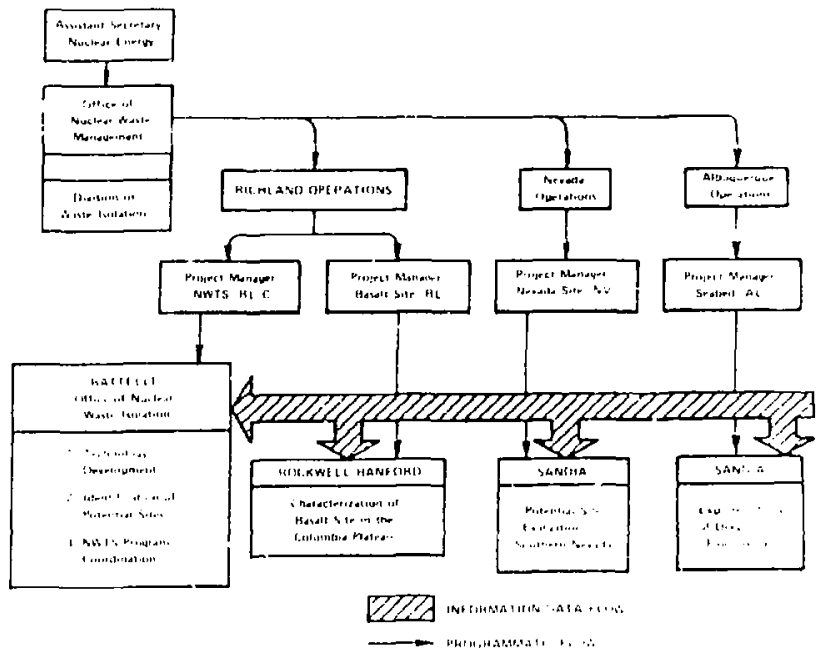

Firure 1. M:- a rogram Management Chart

For the first repositories, only mined caverns in prologic forma ion: within the continontal United states are being considered. An alternatiu. waste disposal concept study recently has been rompluted by Bechtel $x_{i--}$ tional, Inc, for oNwI. ${ }^{4}$ This sudy concludes that the subseabed alternative is the most promising alternative to mined geologic repositorins. and recommends that the deep ocean sediments warrant further study as a waste isolation media. 
The Subseabed Program it managed by Sandis National Laboratories. A comitree of ceclinical experts from oceanographic and academic institutions provide project guidance and review. Periodic peer revicws provide aditional interaction with uninvolved technical experts and continuing assessment of the progran goals and investigations. An international Siobed Winking Group under the auspices of the Nuclear Energy Agency (NEA) , f lise (Irganization Eor Economirs Cooperation and Development (OECD) provilis a forun for discussions, assessment of programs, and p!anning of Eutur: "fforts; coordination of research and joint research cruises and

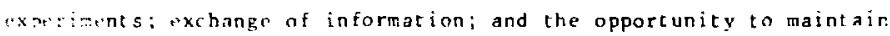
conizunce of international policies and issues which could affect the ancert of subseabed disposal.

A maltivear Subseabed Program Pian' was issued in January 1980. It sitions in somp detail the current and planned activities. It is governed hy the ronsciousness that, even though nur understanding of cepp ain selimentar geologic formations andicates that they are repository

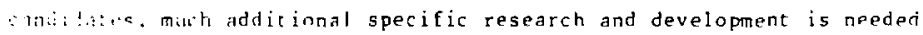
r. i.r the feasibility of the concepr can be considered as having bean

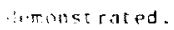

Subseabed Prozram Plas: Stracegy and Management Methods

\section{? $\mathrm{r}$ ara}

$\because$.. primity obiective of the Subseabed Disposal Prograr (SDP) is to fs, $s$, the teinfical, erviconmental, and enfineering feasibility of disfosir: r processed and packaged high-level nuclear waste or repackaged spent reastor fue: (SF), or both, in gr. logic formations beneath the world nc.ar. Hizh-lavel waste $(\mathrm{HLW})$ and $\mathrm{SF}$ are considered the most difficult af radinactive wastes to dispose of in nceanic geologic formations because 0 : the-ir hent and radiation outputs. From a scientific standpoint. tisnosa: of other nuclear wastes, such as transuranic (TRU) and low-level wastes, and materials from decommissioned facilities are a subset of this prortar. If subseabed disposal is found feasible for the most difficult 
wastes, then other factors such as cost will become dominant in deter-

mining the use of the oceanic regime for other nuclear wastes, A

secondary objective is to develop and maintain a capability to assess rhe

seabed nuclear waste disposal programs of orher nations.

The SDP is divided into four phases:

Phase 1: Estimation of technical and environmental

feasibility on the basis of historical data.

completed: 1976 .

Phase 2: Determination of technical and environmental

feasibility from newly acquired oceanographic and

effects data. Estimated completion date: 1985-

87 .

Phase 3: Determination of engineering feasibility and

legal and political acceptability. Est imated completion date: 1993-y5.

Phase 4: Demonstration of disposal facilities, Estimated completion date: 2000 .

At the and of each plase of the program, a review is made and concrpi Eeasibility is assessed. This assessment requires both internal and external review. At each of these reviews (go/no-go gates), a comprehensiv. report will be prepared sumarizing the results of that phase. If results indicate that the concept is unacceptable, the program will be terminated and emphasis thereafter will be placed on demonstrating this unacceptability to other nations which are considering using the seabed for Hitis disposal. The main tasks to be accouplished before completion of each remaining phase are discussed in detail below.

\section{Phase 2: Teahnical and Environmental Feasibilicy}

- All units of a systens model must be operational. A mudel containing all parts of the system that address technical and environmental feasibility (biological transport, physicai oceanographic transport, ion transport through sediments, thermal effects on sediments. canister responses, etc) will be made operational but not fully verified through laboratory or field experiments.

- All properties must be bracketed but not necessarily verified. Each unit of the model described above will require certain inrut properties. During this phase, 
gaximum and minimun est 1 mates of all properties vill be iade (brackered), and sensitivity analyses compleced to identify properties that are crtical. Certain of the ilentified critical properties will be acquired through laboratory and field measurements, wh theoe vill not be site-specific.

- Verification tests will be completed on certain property model units. Depending on resources available and the completion dates for sections of the system model, certain sections will be validated through both laboratory and field testing. As an example, the model unit nearest mpletion at this time addresses themal transport through the sediments. It is hoped that an in-situ trarsfer heat experiment (ISHTE), curcently in develofr.nt and plannad for deployment in 1982, will provide -urification data for this section of the model.

- At least one site in each of the northern At lantic and Pacific oceans will bc identified and initially character-

ize. Although the geologic formations of interest are "xpecced to be stable, uniform, and homogeneous over larze areas, many areas have not yet been completely rapped. To be considered acceptable, sizes should be coporraphizaliy mapped and a decailed three-dimensionai uncerstanding of the sedimentary geologic formation inveloped. This task aill be accomplished though a combination of sedinent sampling and ocean-surface and r.ar-bot.on acoustic profiling of the sediments.

- A technizal and environmental feasitility document will make an estimation of impacts on both man and the envirunment, using the total system mode ${ }^{1}$ and the acquired properties. From this and other studies identified in this section, an assessment of technical and environirntal faasibility will be made and the conclusions roinged anc plibi ished.

\section{Phase 3: Engineering Feasibilicy}

- ai: unies af the system model nust be developed and ya' ifitd. All units of the system mode? will be de*oloped, coupled, and verified for both technical and "nvironmencal feasibility through approptiate laboratory ardilor field testing.

- All properties will be verified. Each unit of the system tescribed above re, uites irput properties. During this Fiase, the maximum-...inimum estimates made in Phase 2 will be reviewed, and when required, the property information reined tiroegi additional laboratory and field experiments and measurements. 
- Long-term (15-yr) in-sicu experimente will be iritiated. Several long-term themal experiments using real vaste and appropriately designed containers will be in tiaced to help validate the system models and to fllou testing in real time through the peak hat and radiation per $\vdots$ ad

- A conceptuai design of the total system (from s;ent-fuel itsoharge to the respository) will be comploted.

- Ar Fnginerering Feasibility docunent will be complated and taviewed. A sumary report of the studies in this saction which contribute to the assessment of engineroring feasibility will be compiled and the conclusiuns rovieved and published.

- Several sites in the Atlantic and Pacific oceans will be identified and characterized. Withit the ocranis regime large areas will be mapped in detail, and a threedimensional understanding of sedimentary geologic for mations developed. At the end of this phase soveral acceptable sites should have been ident ified in pas" ocean.

- National and international legal and politicai positinns will be clarified. Since the legal and political implications of the disposal of HLW or spent fuel in geolngic formations under the oceans are unclegr, these must be resolved during this phase of the program.

- A Draft Environmental Impact Statement (DEIS) will be witten and reviewed and a license app:ication submitrad. The DEIS will contain all the informarion and underst anding developed in Phases 2 and 3 , as well as results from long-term experiments and site selection studies.

\section{Phase 4: Demonstracion of Disposal Capabilicy}

- Conceptual Design and detailed designs for thp tota: systam will be completed.

- The license application or permit requestod in phas: 3 will bo received.

- After the license or permit has been received and the conceptual and detailed designs are complete, the dock and ship system. Will be built and tested.

- After receipt of the license and completion ${ }^{c}$ the detailed desicins, the land transportation network will be developed.

- A long-term monitoring network will be developed. 
Two key questions must be answered in order to demonstrate both rechnical and engineering fessibility of subseabed dispossl:

- Is there a barrier or set of barriers, natural or manmade,* that will offer satigfactory containent of radionuclides? The barriers under consideration are

$\begin{array}{ll}\text { Natural } & -\frac{1}{\text { Man-Made }} \\ \begin{array}{l}\text { Sediments } \\ \text { Basement } \\ \text { rock }\end{array} & \text { Sanister form } \\ \text { Ocean } & \text { Sacrificial layers (overpacks) }\end{array}$

- Will these barriers still be adequate after introduction ot waste containers?

These key questions mus: acdress:

- Hole closure following physicar disruption of sediment:

- Eifects of heat

- Effects of radiation

The multibartier concept, developed by the SDP in 1974, assumes a continuously wet environment in which solidified and packaged radionuclides ate placed. The seabed sediments, together with any modifications :o tnem, are the primary bartiers to radionuclide migration. The eanister is considered very important during the initial heat generation period until the geologic formation has returned to essentially ambient cemperatures ( $-309 \mathrm{yr}$ ). The waste form and the water column are supplemental barriers.

${ }^{*} A$ bartier is a quantifiable passive mechanism that dill delay the movement if radionuclides, allowing time for radioactive decay to make the waste less harmful or ultimately harmless. 
A reference disposal syotem has beea established for purposes of assessment and programatic planning. even though that system may have to be 3 ltered as additional information is required. The reference system was chosen on the basis of simplicity, completeness of emplacement technology, and estimated cost. The reference subseabed geological disposa: system involved the placement of appropriately treated wastes or spent reactor fuel in a container which will be placed into clayey sediments away from the edges of ocearic tectonic plates (to avoid volcanic asid seismic activity), anc away from the edges of major circular surface currents (to avoid subsurlace agitation and resource exploitation associated with these currents). The abyssal-hill areas of the ocean bot tom covered by this definition are designated mid-plate/mid-gyre (MPC) areas.

Several emplacemeat methods appear feasible, though none have been developed in detail. We are conceptual!y consider:ng penetrators, winchcont niled injectors, trenching or drilling to emplace wastes at a substantial depth beneath the sediment surface.

\section{Erogram Structure}

The frogram has been subfivided into seven major activities, whith have been further divided into tasks and subtasks for the purpose of organizazion, planning, ano reporting accomplishments in a logical and consistent mannet. The abbreviated program outline follows.

Activbicy A: Sice Studies -- To find areas in the oceans that satisfy the site selection criteria; to select one or more sices fron pach area, and to survey them. At present, because of limited funds, only areas in tin North At lantic and North Pacific are being assessed.

Activity B: Environmental Studies -- To supply data and information for the Risk/sufecy Analysis, transportation, and Site Studies activities of the program. These cudies include the phrsical and biological sections of the Subseabed Disposal Progran. 
Activity C: Multibarrier Identification and Quantification -- Tn idenrify and quantify both natural and man-made barriers that could be interposed between buried wastes and mankind; ca evaluate way : n which

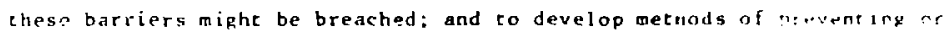
counteracting such breachment.

Activity D: Emplacement of Wastes L!l Sediments -- T develop twhnical understanding of the benefits of the various emplacenent methods (e.k., penetrometer, injector, crench, and drill), make cost estumates, and dewenstrate' th $a$ concept.

Activity E: Transportation -- To deselop th, necrssarv torhron:ab: : reve suitablv packaged wastes or spent fuel from the originatas a an: : the dcck facility, thence by ship to the disposal area, and tr. mplate th. waste package in the subuarine geologic formation.

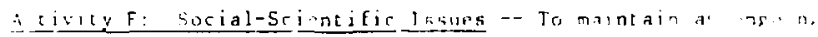
paluation of legal and institutional structures in the 2.5 . and other crunt $r$ es relating to seabed disposal; to similarly survey ari political at itules: to furnish information by which any nation can form insti-1:tional structures for the proper use and control of eubseabed disposal: and to insure that data needed to support lezal, sccial, and politicat discussins are collected ani evaluted as a bosis for tecisinn.

Activity G: Risk/Safety Analyses -- Use all available inforntion in predirt the degree of risk and the amount of environmentai impact ixpercid from all phases of the Subseabed Disposai Program.

Figuro 2 shows the current schedule for the total program This schedule is tightly interrelated to program funding. 


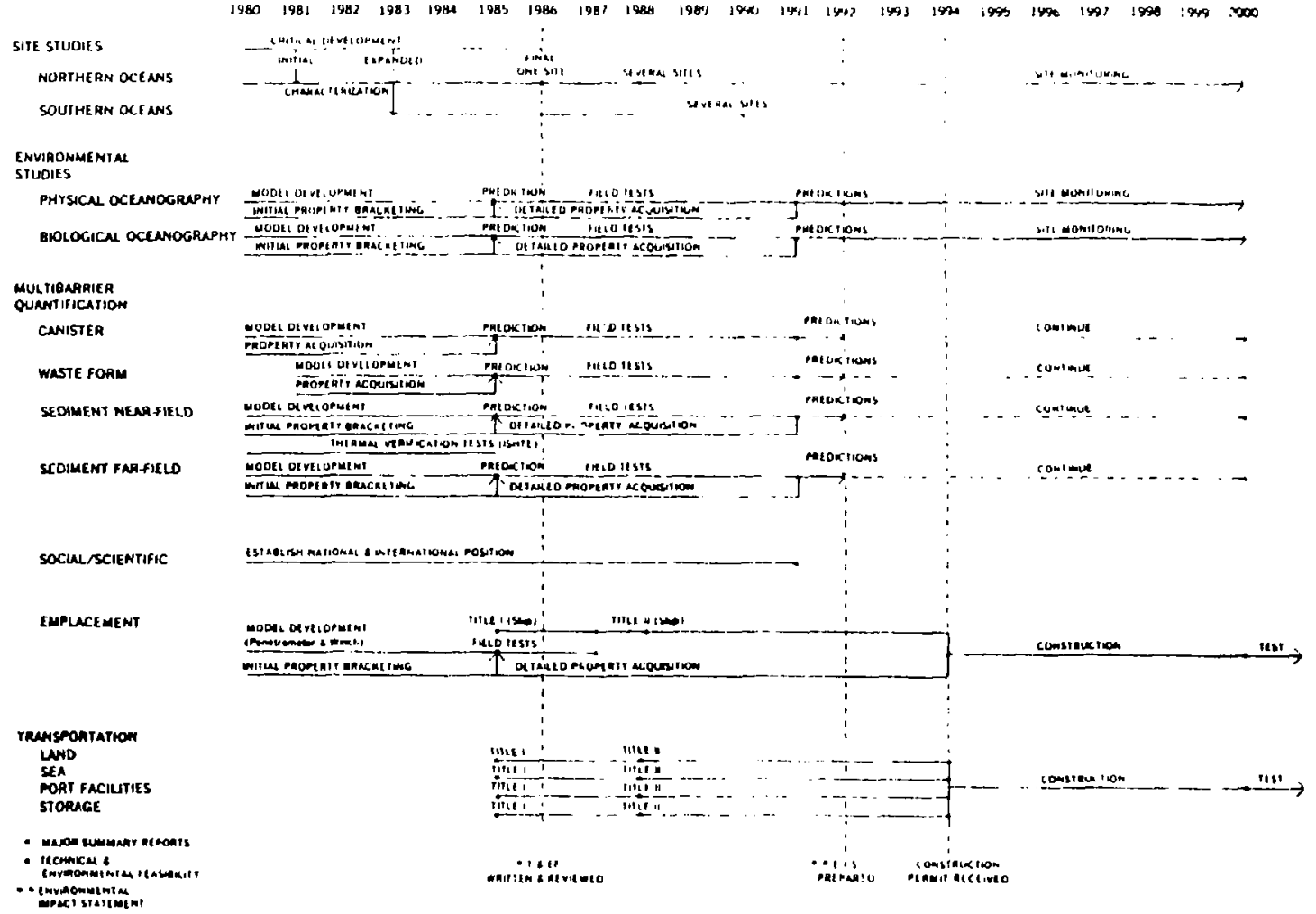


In order to most froductively ure the limited resources available for assessment of the waste disposal potential of the geologic formations tementh th" world oceans, effective site selection and management s. rat"ains mut bremployed. These strateries for the program can be broker thom into two parts. The first addresses the process for selection of niptable zeologic formations. The sezond addresses the process whict istisass the tachnical, environmental, and engineering feasibility of anditic disposal benteath the oceans.

\section{Sirtegg for sice ocudies}

Eins. tic geologic formations beneath the ocsans fep sa vast wartige about 70 , of the surface of the globe) and the resources

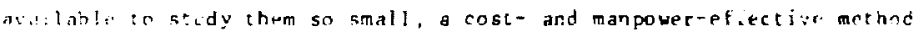
was divelinped to focus the site studies. A group of leading $t^{t}, \mathrm{~s}$. octanof:aphers was given the task of develcping a methodology which would allow. after the approptiate research was completed, acceptable sites to bo identifiad. The approach being implemented involves

- Deveropmenr ef a list of exclusion criceria through wich the rlobal zrea under consideration could be decreastd to a somewhat sore manageale size

- Fanking of the areas not excluded in scep I using all available historical data

- Accuisition of additional generic information for thr smaller areas of incerest

- Aquisition of site-specific ranking data

- Sn?ection of one cr more sices in each ocean from those still consideré acceptable for long-term engineerinp assessment studies. The sice selection process is described in more detail in a paper by Laine, et al.

\section{Stracegy for Barr: Assessment}

Since the processes within some of the mare promising oceanoraphic geologic fornations are very slow, and since the decay times of some of the radionuclides are very long, it was apparent that the most efficient 


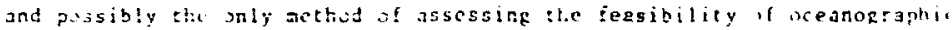
geolopic disposil vould be through the development and use of predictin. midels and computer codes. Medels and codes alone, however, are lneffective if not sipportad by sound regearch and sield data. The approach taing

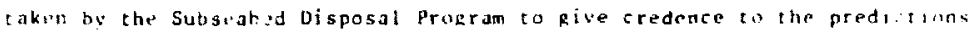
made by the codes and models is shown in Figure 3. The first stou s $t$

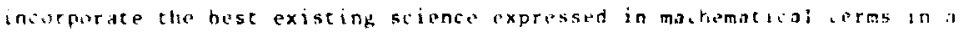
sot of models and codes which describe a funtion or process occurring isubseabed jisposa!. Second, it will be nex. isary to acquire from the historical icerature or through laboratory measurements necessary propertips to ise the codes and models correctly. Thitd, completw sensitivity atudips must be made of each section of the model, identifying propertics that at ically al bect the outputs. Fourth, veriliable predictions must br madp bastid on the models, cores, and property esimites. Fifth, camplete lab ur fieid axperimants must be performed whach an be used to vaitidi. ibe models, codes, and properties. If the predictions from a section of the model and evdes agree with the freld experiments, then that section will b. coupled with other sections to yield an overall systems-predictive model. If thr pretictions and validation experisants do not azse, then the model will be refin.d and the property data improved.

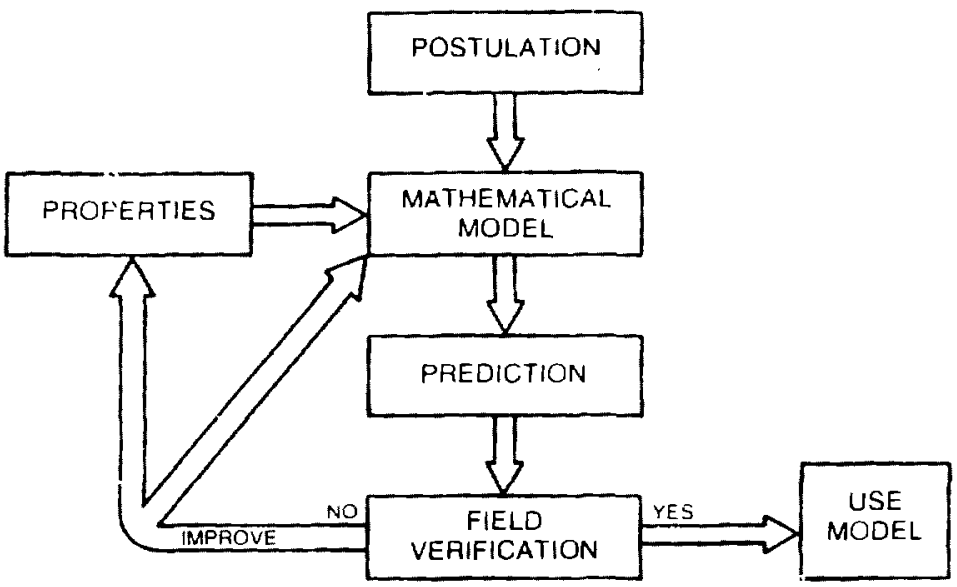

Figure 3. SDP Research Approach 
'n urder a manage the SDP and move mose rapidly toward the goa! of . siment of the foasibility of subseabed high-level waste and spent-fuel

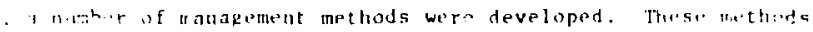

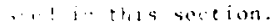

$\therefore$ - $\quad \therefore$ irtingring

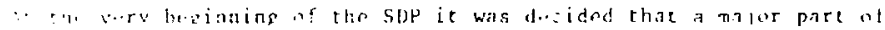

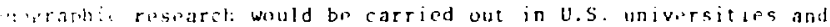

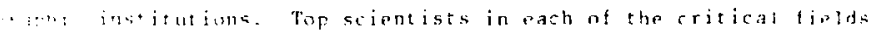
i. "athe have been reteruted t" work weth Sandia researchers and

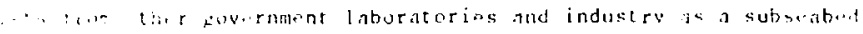

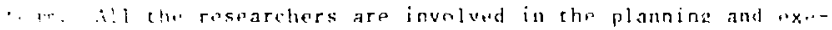

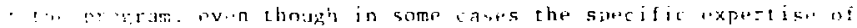

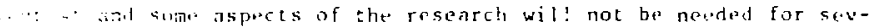

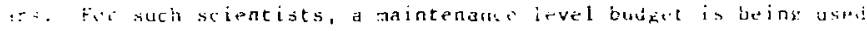
-.. : h. involved in the program. Convessely, university seientists

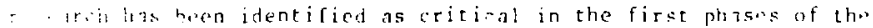
.... I.. Fundid to a maximum of $30 \%$ of their cotal annual research

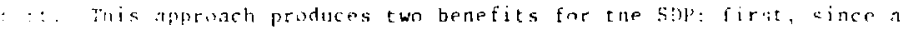

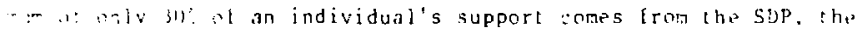

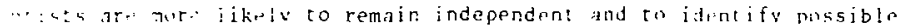

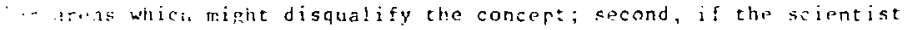

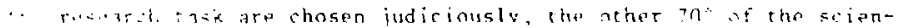

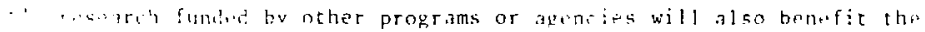

$\because \cdots$ thes inberactions, as will as hy tirect and continisus ax-

$\because$ antwern ifffiront puvernment agenries (FPA, NRC, NSF, ISX, NOAA, . as is aditiond information is avilable for use by the SDP. A

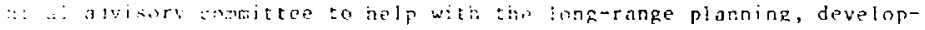

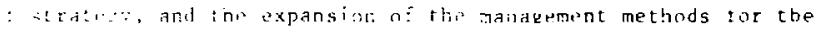

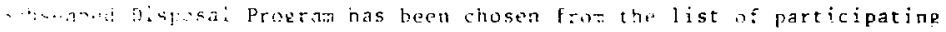
l.inisis 


\section{Periodic Revisw of the Program}

The prezram has been Jesigned with projetermined tines for technical and peer review. These reviewe are consiaered ac each go/no-go decisian point at the end of the technical and environmrntal fearibility, the engineering foasibility, and the pilot production phases. In addition to thes tajor reviews, a yearly publication of all data is prepared and widely distributed for review. An annual meeting is held with all SDP principsl investigators, at which the past year's resparch is discussed and reviewed by the other scientists within the Subseabed Program. When a piece of researcil t.as been completed, the program strongly encourayes the investigators involved to publish their data and results in the open litrrature where they can be reviewed by the public and the scifn-ific community at iarge.

At the end ot each inajor section identifled above, an additional outside review of the progran and of the indi"idual lasks will bo made by an cminent group assembled by the iational Academy of Science or a comparable organization. This review will accomplish two things: first, the reviewers will be asked to identify any problem areas which have been overlooked by the Subseabed Program; second, and more imfortantly, they will be asked to make an independent assessment of the validity and acreptability of the Subserbed Disposal Progran at that phase of its development.

In addition to the participants mentioned above, an international Subseabed Horking Group was established under the Nuclear Energy Agency OECD has been developed. In addition to exchanging information on specific research topics of interest, this group reviews, on a yearly basis, the research of the six countrifs involved in the assessment of geologic disporal beneath the oceans. This review has as one of its goals, the identification of any uncertainties which might make the concept unacicptable.

\section{Activity Chart and Program Plan Development}

Early in the development of the program, the Technical Advisory Committee (TAC) decided that a program plan and an activity time line 
shart identifying individual reaearch caske was neceasary. The program plan was prepared in two parts: Volume I i 6 a description of a multiyear plan for the program; Volume II contains a detailed breakoow of the individual acivities for any single year, and identifies the principal investipgiors, tasks, and funds available to accomplish thoce tasks. Fach

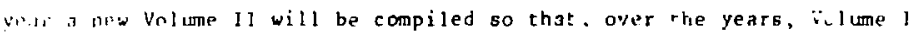
andi strveral Volume Ils will show how the program is 'rogressing toward its stated mals. The activity chart is a tool which gllows the program minngers and the TAC ro monitor the progress of the program in a logical, step-wise fastion. It ilso allows for the rapid identification and marshalling af assistance in areas in which unforeseen problems might arise.

Since the evaluation of the technological, puvironmental, and econom:al feasinility of subseabed emplacement is the central purpose of the sLP. and since no definite conc:usions as to these aspects have yet bepr. reached, a definitive and complete delineation of the political, legal, and regulatory aspects of this emplacement option must of ne-tasicy await further progress within the overall program plan. However, the engineered enplacement of radioactive wastes wictin the subseabed geologic formation is at prisent considered to be a viable disposal option on a tentative, prolininary casis. Accordingly, the SDP incorporates a m'llidisciplinary ffort to identify in an ongoing fashion insticutinnal, legal, and regulatory problems on a national and an international basis.

A primary concern is, of course, to ensure that the conduct of the frogram and the froposej subseabed emplacement mode be in fuil and ongoing compliance with applicable laws and regulations of the United States. To ensurp compliarce with the provisions of the National Environmental Poliry $A-t$ (ivEPA), the SDP maintains an ongoing action to establish and maintain full and accurate documentation. Those evaluations required by law are therefore being anticipated and a documentary basis is being provided to faciltrate their being performed with the optimum intellectual rigor.

The public participation and response requirements under NEPA are being provided for. The sDP has initiated longterm planning in chis respect as to identify public concerns at an early date in order to 
aduress them in a forthright manner, within an educational context, within the parameters of our political processes, and within a "feedback" process which might effect further scientific, technical, and environmental investigation. An ongoing series of interviews is preeently planned with concerned citizens in this field in order to iniciate she public participation process.

The SDP recognizes that political acceptance of the orerall conzept, should it prove ultimately feasible, is $n^{f}$ the utmost importance: for ihis reason, in addition to the general public education efforts, we will atrempt to maintain liaison with interested legislators to praide tham with the necessary background information and to work with them on any pertinent Legislation which might ultimately be deemed appropriate by them.

On the national tcene, at present, there is no explicit statutory and rezulatory regime which deals with subseabed emplacement directly. Fur.ther technical information will have to be evolved befo:e it can be tofiniteiy determined whother additional regulation is required. At present, even though the Ocean Dumping Act prohibits ocean cumping of high-level wastes and provides for EPA licensing of low-level dumping, this statute simply does not reach th - subseabed emplacement mode (a disposal methodology radically diff",ent from dumping in the legal, technical, and environmental senses).

Because of the very nature of the emplacement mode under consideration, international and multinational political and legal concerns are an important consideration of the Progran. Under the recent Presidential Executive Order designating ocean seabed areas as the "world's commons" and requiring the evaluation of the erfects on foreigr nations by a proyram such as this one, possible favorable geo-political aspects of subseabed emplacement are receiving intensified evaluation. Ir essence, one prinary geo-political advantage of the subseabed option, if made available to other nations, will be to afford an alternative to thosa nations who lack a tercestrial storage or disposal opticn for high-level wastes. Without such an alternative, such nations might be forced to "bargain" 
with othe nations having large uninhabited areas for atorage rights, and the necessary price might well be the trangfer of igigh-level nuclear technology under inappropriate circumbtances; the latter might well have a distabilizing effect on worldwide nuclear arns nonproliferation.

tiven though a multinational or international regulatory regime dea! ing with subseabed emplacement might well be a preferable alcernative, rhe leral bitsis should be maintained to preserve this disposal option on a unilatiral national basis if that should ultimately prove to be necessary ind advisabli'. In that connection, it would be most unfortunate if the urrine maging law of the Sea negotiations under U.N. auspices were to la.k: to any international legal impediments against the subseabed option slurild it prove to be otherwise viable. The SDP will thereforc maintain liaisun with concerned U.S. officials involved with the negotiations in wrin: :" provide them information as to the program's progress in order co minimian the possibility of future legal impediments to U.S. action in this regard. Notwithstanding this concern, cooperation with interested fortin governinents and international agencies remains a primary concern of thu program. The International Seabed Program is a major menns of wibrosing 2 it is concern

As in the U.S, no international treaties, laws, or regulations di$r$ ot $1 \because$ address the subject of controlled emplacement of waste within the subseabed geoloriral formations, in contrast co ocean dumping, which has reanivid considerble attention.

Iis: L.S. has not disposed of any radioactive waste in the ocean since i ia; inwever, several European nations dispose of low-level waste under the argis of the Nuclear Energy Agency (NEA) of the Organization for Economic Cooperation and Development (OECD). The NEA requires prior notifica$t$ ion and consultation between NEA member nations is we 11 as supervision of dumping operations by NEA representaives.

An international agreement on ocean dumping was reached in December, 1972, resulting in the London Convention on ine Prevention of Marine Pollution by Dumping Wastes and Other Matelials. It prohibits the dumping 
of hiph-level wastes and reauires bpecial permits for the dumping of other than high-lpvel radioactive wasts. Provisjonal definitions and recomendations conceraing the dumping of radionctive wastes have been issufd by iAEA and arf being used by the London Convention contracting parties.

In its ongoinc concept feasibility assessments, the SDP wi'l contisuo :a evaluate the above-discussed political, legal, and insticcional marcerns to nsura that, in the event the concept is wlo imately foasiole, che national and international regulations will be in phase with this fow tochnology so that it can be legally implementent if cesired.

\section{Reierencrs}

${ }^{1}$ DOE/ER-IIONG/D Report of Task Force for Review of Nuclear Waste Management, February 1978.

${ }^{2}$ TiD-29442 Report to the President by the Intcragency Revipw Croup on Nucleas Wast Management, March 1979.

${ }^{3}$ DoE/EIS-mMLfiD DraEt Environmental Impact Staterent, Management of Commercially Generated Radioactive Waste, April $19 \% 9$.

4 Becheel National, Inc., Alternative Waste Disposal Cone Drs, An Interim Technical Assessment, DNWI-65 (Draft).

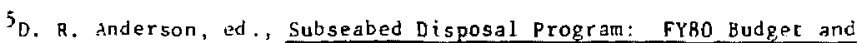
Subtask Work Plans, Volumes I and II, SAND80-0007/i, (Albuqueraue: 5and is? Laboracories, January 1980). 